\title{
Contribution to the knowledge of terrestrial molluscs in southeastern Ukraine
}

\author{
Igor A. Balashov ${ }^{1}$, Sergey S. Kramarenko², Alexander V. Zhukov ${ }^{3}$, Andrey N. Shklyaruk, \\ Alexander A. Baidashnikov ${ }^{1} \&$ Alexey V. Vasyliuk ${ }^{1}$ \\ ${ }^{1}$ Schmalhausen Institute of Zoology, National Academy of Sciences of Ukraine, B. Khmelnitsky str. 15, Kiev, 01601, Ukraine, \\ e-mail: igorbalashov@ukr.net,vasyliuk@gmail.com \\ ${ }^{2}$ Nikolayev State Agrarian University, Parizhskoj Kommuny str. 9, Nikolayev, 54010, Ukraine, e-mail: kssnail@rambler.ru \\ ${ }^{3}$ Dnepropetrovsk State Agrarian University, Voroshilova str. 25, Dnepropetrovsk, 46000, Ukraine, \\ e-mail:zhukov_dnepr@rambler.ru
}

\begin{abstract}
Balashov I. A., Kramarenko S. S., Zhukov A. V., Shklyaruk A. N., Baidashnikov A. A. \& Vasyliuk A. V., 2013 : Contribution to the knowledge of terrestrial molluscs in southeastern Ukraine. - Malacologica Bohemoslovaca, 12: 62-69. Online serial at $<\mathrm{http}: / /$ mollusca.sav.sk $>10-J u l-2013$.

Records of terrestrial molluscs collected in nine scattered sites in southeastern Ukraine are presented and discussed. The findings of non-native Helix lucorum and Lucilla singleyana are especially interesting. Coloration of H. lucorum in different parts of its range seems to be significantly different. A role of keel in species determination of collected Helicopsis sp. shells is discussed. Variability of Deroceras subagreste coloration is described. New data on a species composition of terrestrial molluscs in several protected areas is given.
\end{abstract}

Key words: terrestrial molluscs, Gastropoda, Helix lucorum, Lucilla singleyana, Helicopsis, Deroceras subagreste, Ukraine

\section{Introduction}

Southeastern Ukraine is a dry area with the predominance of open, steppe landscapes. Natural forests occur here mainly in the valleys and ravines. This region is industrial and densely populated, thus natural habitats are very restricted here. However, in its highest part, Donetsk Upland, some interesting Pontic and endemic species occur. In present, southeastern Ukraine is one of the least studied parts of Ukraine regarding terrestrial molluscs. Available information was summarized recently BALASHOV \& GURALSverlova (2012) and Gural-Sverlova et al. (2012). Several Caucasian species were found here and three new species were described for the science. However, distribution and ecological preferences of the terrestrial molluscs in this part of Ukraine are still less known. Some notable materials were collected in different parts of southeastern Ukraine between 2004 and 2010, however without precise location using GPS coordinates. These materials are too scattered to give any overview about molluscs of any certain separate area, but this data significantly contribute to the previous reviews about terrestrial molluscs of southeastern Ukraine (BALASHOV \& GURAL-SvERLOVA 2012, GurAl-Sverlova et al. 2012). It should be specified that this work is not a review of all data regarding terrestrial molluscs of southeastern Ukraine or some smaller separate area, but only a new contribution to previously known data.

\section{Materials and methods}

Materials were collected and processed by standard methods during 2004-2010. All examined materials are kept in the Collection of terrestrial molluscs of Schmalhausen Institute of Zoology (Kiev).

Surveyed sites (Fig. 1) were:

1. Dnepropetrovsk region, Ordzhonikidze Town, suburb, plantations of black locust (Robinia pseudoacacia) and English walnut (Juglans regia) (2010, Zhukov A. V. leg.) 2. Zaporozhye region, Tokmak district, near Tokmak Town (2006-2010; Balashov I. A. and Vasyliuk A. V. leg.)

3. Zaporozhye region, Vasylivka district, near Skelki village, Velykyj Lug National Nature Park and its vicinities (10.-20. 08. 2010, Vasyliuk A. V. leg.)

4. Donetsk region, Donetsk City and Makiivka Town, urban landscapes (2005, Shklyaruk A. N. leg.)

5. Donetsk region, Svjati Gory National Nature Park (2005, Shklyaruk A. N. leg.; 2006, Vasyliuk A. V. leg.)

6. Donetsk region, Starobeshevo district, vicinities of Starobeshevo urban type settlement and Rodnikove village (2005, Shklyaruk A. N. leg.)

7. Donetsk region, Mariupol City (2004, Shklyaruk A. N. leg.)

8. Lugansk region, Sverdlovsk district, vicinities of Provallya village, Provalskyi Step branch of Lugansk Nature Reserve, maple-ash forests in ravines and valleys, and a steppe (31. 05. - 03. 06. 2004, Baidashnikov A. A. leg.) 9. Lugansk region, Sverdlovsk district, near Nagolno-Tarasivka urban type settlement, an oak-poplar forest and adjacent meadows and steppe, 170-230 $\mathrm{m}$ above sea level, (16.-18. 04. 2010, Balashov I. A. leg.) 


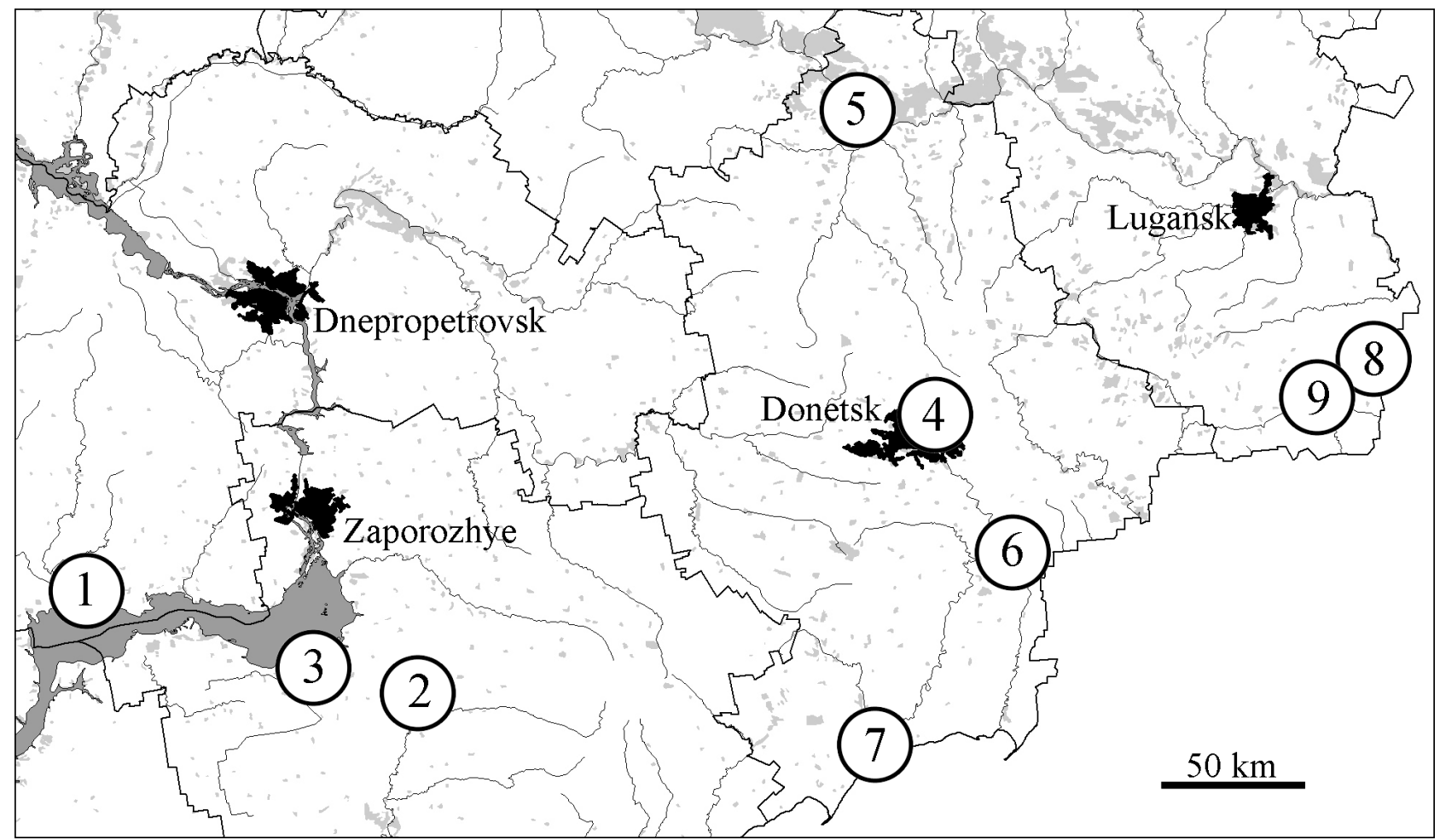

Fig. 1. Location of the surveyed sites.

In most of these locations, only occasional observations took place and probably not all mollusc species were revealed. Only locations number 2, 8 and 9 were surveyed intensively in the field during several days and also litter samples were taken. At least here, most of terrestrial mollusc species were probably revealed.

\section{Results and discussion}

In the suburb of Ordzhonikidze Town (locality No. 1), such species as Vallonia pulchella (Müller, 1774), Brephulopsis cylindrica (Menke, 1828), Chondrula tridens (Müller, 1774), Monacha cartusiana (Müller, 1774) and Helix lucorum Linnaeus, 1758 were found. Finding of the latter species (Fig. 2A) is of particular interest. A native range of this species lies mainly in the Central and Eastern Mediterranean region (Schileyko 1978, Sysoev \& Schileyko 2009, Welter-Schultes 2012). In Ukraine, H. lucorum occurs in the Crimean Mountains, where this species is known since $19^{\text {th }}$ century, but it is not clear whether it is native here (BALASHOV \& Gural-Sverlova 2012). In 2012, a colony of this species was reported from Odessa City (southwestern Ukraine) (Khlus \& TкаснUк 2012). Our report of H. lucorum from Ordzhonikidze is the second report from Ukraine outside Crimea. It is no doubt that H. lucorum is a non-native species in this part of Ukraine. Currently a numerous population lives near Ordzhonikidze. Besides plantations of Robinia pseudoacacia and Juglans regia these snails live here also in the area of abandoned fields. Local people report that this species appeared massively in 2002, attracting attention by its large size, and now it occurs in many places around Ordzhonikidze Town. Fifty-nine specimens of $H$. lucorum were collected. The height of the collected shells is up to $44 \mathrm{~mm}$, width is up to $43 \mathrm{~mm}$ at five whorls. Umbilicus ranges from fully closed to half opened, in most cases it occurs in a form of a narrow chink. Shell surface consists of an irregular radial strong striation with weakly pronounced spiral grooves. Coloration of all shells is represented by dark wide spiral stripes and clear light band between them (Fig. 2A). Such coloration with light band clearly distinguishes this colony from Crimean populations of H. lucorum (so called Helix lucorum taurica Krynicki, 1836), where such pattern is rare and, if present, it is pronounced much weakly. The main coloration of Crimean populations is formed by dark radial stripes on light background; spiral coloration is often absent and if present it is very weak and unclear. Coloration with predominance of the spiral elements in H. lucorum seems to be characteristic of the main part of its range (WeLter-SCHUltes 2012). This can signify that $H$. lucorum from Ordzhonikidze does not have Crimean origin, but probably a more distant one. In 2006, specimens of similar coloration as Helix lucorum var. martensii Boettger, 1883 were reported from Kerch Peninsula in the eastern part of Crimea, where this species was not registered before (LEONOV 2006). A similar shell of H. lucorum is shown in a photograph from Penza City (central European Russia) in the work of Sтоуко \& BuLAVKINA (2010). A population from Odessa also has similar coloration (KhLus \& TKACHUK 2012). In the same time, in work of Stoyko \& Bulavkina (2010) in a photograph from the Belgorod City (western European Russia), a shell with "taurica" coloration is shown. Specimens with "taurica" coloration were also reported from Russian part of Caucasus (Schileyko 1978). In the light of this Schileyko (1978) did not recognize Crimean subspecies. However, in our opinion, this problem should be studied in more detail, because the coloration seems not to be very variable within isolated Ukrainian populations. It is probable that this subspecies is actually not Crimean, but Crimean-Caucasian. Another possible option is that specimens with radial coloration were introduced to Caucasus from Crimea, 


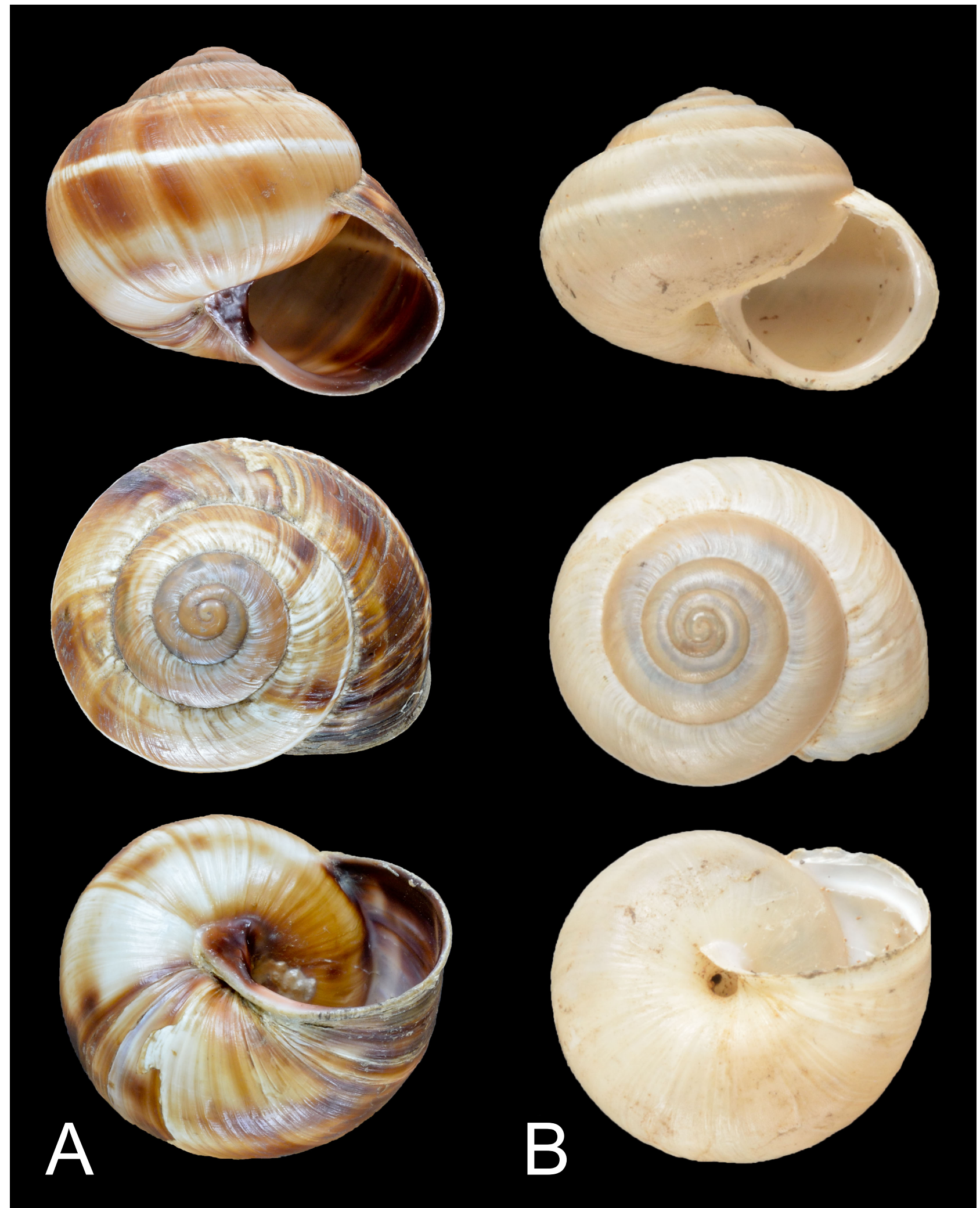

Fig. 2. A - Helix lucorum, Ordzhonikidze, shell width 42 mm; B - Harmozica ravergiensis, waste bank of Kalinin mine (Makiivka), shell width $12 \mathrm{~mm}$. Photo by A. A. Baidashnikov.

as well as to Belgorod (see above), and were mixed with local Caucasian H. lucorum.

Areas to the north and to the west from Tokmak Town (locality No. 2), with such habitats as steppes, sparse forests and shrubs, riparian meadows and forests around Chyngul River, were studied quite intensively between 2006 and 2010. However, in the most of these territories, terrestrial molluscs were represented only by various combinations of C. tridens, V. pulchella, Vallonia costata (Müller, 1774), Succinella oblonga (Draparnaud, 1801) and Vitrina pellucida (Müller, 1774). Such species composition seems to be a typical for many habitat types in the most part of southeastern Ukraine. C. tridens and V. pulchella are two most frequent species there. Other species in this region occur mainly in the various isolated habitats. In such a way, in steppes near Tokmak Town, Helicopsis cf. dejec- 


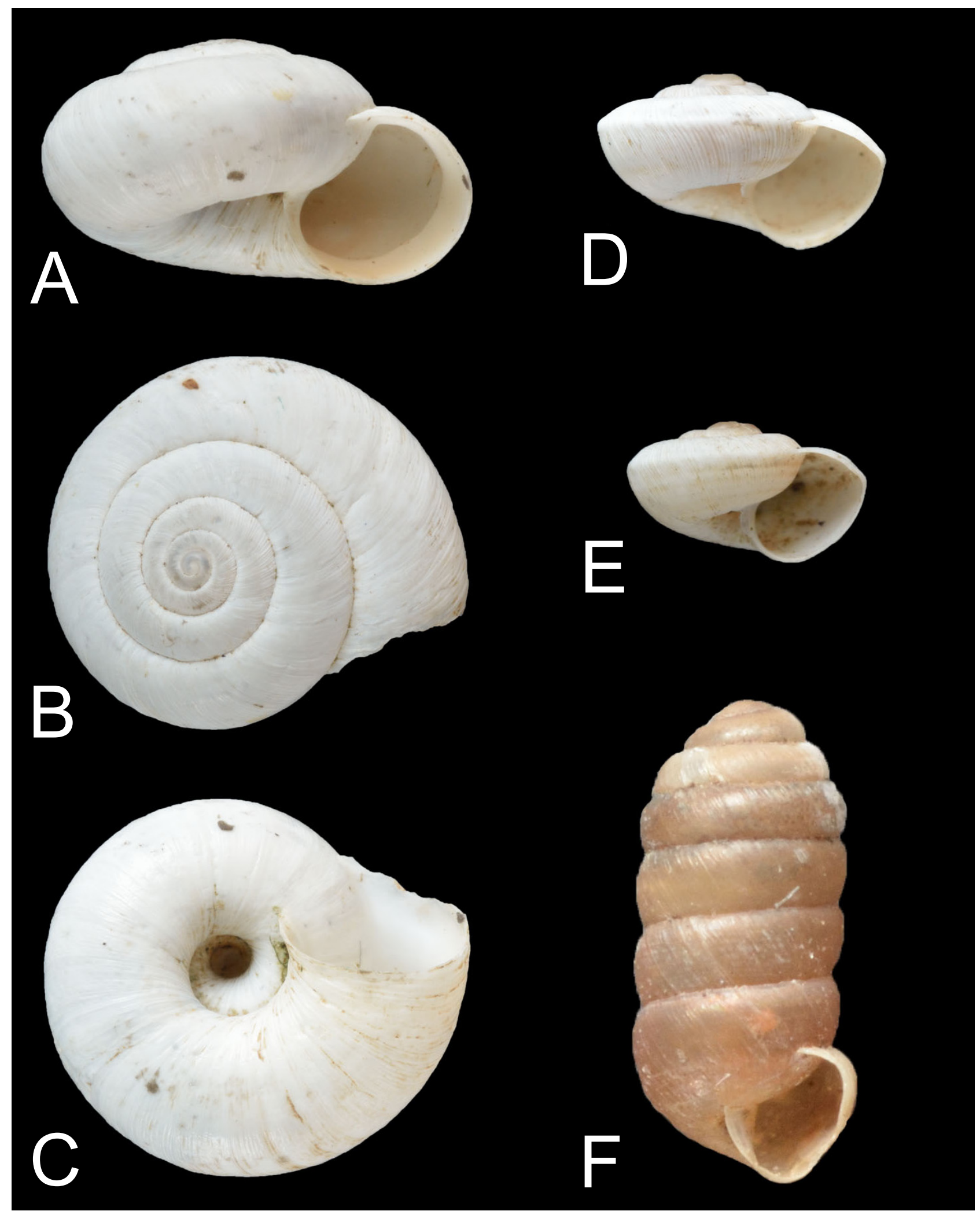

Fig. 3. A-E - Helicopsis sp. from Velykyj Lug National Nature Park, shell width $12 \mathrm{~mm}$ (A-C), $5.6 \mathrm{~mm}$ (D) and $4.7 \mathrm{~mm}$ (E); F - Pupilla sp. from Mariupol, shell width $1.7 \mathrm{~mm}$, shell height $3.6 \mathrm{~mm}$. Photo by A. A. Baidashnikov.

ta (Rossmässler, 1838) was found only on one small site with limestone outcrops. Moreover, in an isolated riparian forests along Chyngul River near Chervonogirka village, slugs Deroceras laeve (Müller, 1774) and Deroceras subagreste (Simroth, 1892) were found.

In Velykyj Lug ("Great Meadow”) National Nature Park (locality No. 3), C. tridens, V. pulchella, Monacha fruticola (Krynicki, 1833) and Helicopsis cf. martynovi Gural-Sver- lova, 2010 were found. Only empty shells of the latter species, on the contrary to the other three, was found only in some sites of natural steppes. Unfortunately, it is impossible to clearly identify $H$. martynovi solely based on external characters (GURAL-SVERLOVA 2010). Nevertheless, conchologically, this species is similar to $H$. martynovi, as all its juvenile shells have weakly pronounced keel (Fig. 3D-E), which is absent in all adult shells (Fig. 3A-C). According 
to Gural-Sverlova $(2010,2012)$ among Ukrainian species this is characteristic of H. martynovi and Helicopsis retowskii (Clessin, 1883) only. The latter species is mainly Crimean and probably was introduced to some mainland areas of Southern Ukraine (Gural-Sverlova 2012). Other Ukrainian Helicopsis species, according to GURAL-SverLOVA $(2010,2012)$, either have no keel or it is present in both juveniles and adults. Because our shells were found here in natural protected steppe habitats, we suppose that this Helicopsis species seems to be clearly native in this area. This is the most western record of Helicopsis species similar to $H$. martynovi.

On the other hand, in above mentioned population of $H$. cf. dejecta (locality No. 2), some juvenile shells have a weak keel or peripheral angle and some do not. Therefore, this character seems not to be so important for the species differentiation as it is probably strongly depend on habitat conditions. In the snails of the genus Rhagada from Dampier Archipelago (Australia), shell morphology within one species is extremely diverse (STANKOWSKI 2011) in similar way to Ukrainian Helicopsis species. The height of shells, keel and striation in Rhagada are extremely variable depending on environmental conditions. Presence of keel seems to be characteristic of Rhagada populations that live in rocky habitats (STANKOWSKI 2011). Maybe the same situation is characteristic of Ukrainian Helicopsis. Differences in the anatomy that were used by GURAL-SvERLOVA $(2010,2012)$ to distinguish among Helicopsis species are based on the length and width of some reproductive system elements. Many more specimens should probably be studied to clearly separate species by such quantitative characteristics. It seems that at least south Ukrainian Helicopsis filimargo (Krynicki, 1833), H. dejecta $[=H$. arenosa (Krynicki, 1836)], H. retowskii, H. gasprensis (Hesse, 1934) [=H. paulhessei (Lindholm, 1936)], H. martynovi, $H$. subfilimargo Gural-Sverlova, 2010 and $H$. luganica Gural-Sverlova, 2010 are closely related and expearence some transition forms. In our opinion, it is unlikely that all these forms are in fact separate species. This problem requires much more detailed study. This is especially important, as at least in southeastern Ukraine all Helicopsis species seems to be threatened. They live mainly in the natural steppe habitats, which decline recently in Ukraine (PARNIKOZA \& VASILUK 2011).

In urban landscapes of Donetsk City and adjoined Makiivka Town (locality No. 4), Succinea putris (Linnaeus,
1758), B. cylindrica, C. tridens, Zonitoides nitidus (Müller, 1774), V. pellucida, Cepaea vindobonensis (Férussac, 1821), Helix albescens Rossmässler, 1839, M. cartusiana, Xeropicta derbentina (Krynicki, 1836) and Harmozica ravergiensis (Férussac, 1835) (Fig. 2B) were found. The latter Caucasian species was found in Makiivka in few localities, mainly in the waste banks of mines. This species was mentioned in Ukraine for the first time in 2006 from Dnepropetrovsk and Donetsk regions and was also registered in Western Ukraine recently (GURAL-SverLova et al. 2012, Balashov \& Gural-Sverlova 2012). It is not clear whether this species is native in southeastern Ukraine, as terrestrial molluscs of this area were almost not studied before 2006. However, because it lives mainly in anthropogenic habitats, and it was recently introduced to Western Ukraine, it seems much more likely that this species is not native in Ukraine.

In the various habitats of Svjati Gory ("Holy Mountains") National Nature Park and its vicinity (locality No. 5) S. putris, V. pulchella, V. costata, Cochlicopa lubrica (Müller, 1774), Cochlicopa nitens (Gallenstein, 1848), C. tridens, Punctum pygmaeum (Draparnaud, 1801), Perpolita hammonis (Ström, 1765), Perpolita petronella (Pfeiffer, 1853), Z. nitidus, C. vindobonensis, Fruticicola fruticum (Müller, 1774), Pseudotrichia rubiginosa (Rossmässler, 1838) and $H$. cf. martynovi (its type locality is situated here) were found. Such number of hygrophilous species is quite unusal for this region. Cochlicopa nitens and P. petronella are particularly rare in southeastern Ukraine.

In the center of Starobeshevo district (locality No. 6) $V$. pulchella, V. costata, Truncatellina cylindrica (Férussac, 1807), C. tridens, V. pellucida, C. vindobonensis, S. oblonga and Lucilla singleyana (Pilsbry, 1889) (Fig. 4) were found. It is a second reliable record of L. singleyana in Ukraine. Only a single shell was collected together with above mentioned xerophilous and generalist species. The shell width is $2 \mathrm{~mm}$, height $0.8 \mathrm{~mm}$, spire height about $0.1 \mathrm{~mm}$ and the suture is relatively deep. This shell is colorless and translucent, thin-walled, smooth, and of 3.5 whorls. Umbilicus is very wide, perspective; all whorls are clearly seen through it. Umbilicus width is about $0.6 \mathrm{~mm}$, i.e. almost $1 / 3$ of shell width (Fig. 4). We had mentioned this finding for Donetsk Upland recently, without description and other details (BAlashov \& Gural-Sverlova 2012). Earlier, this species was reported for Ukraine as Helicodiscus singleyanus inermis Baker, 1929 from Tran-

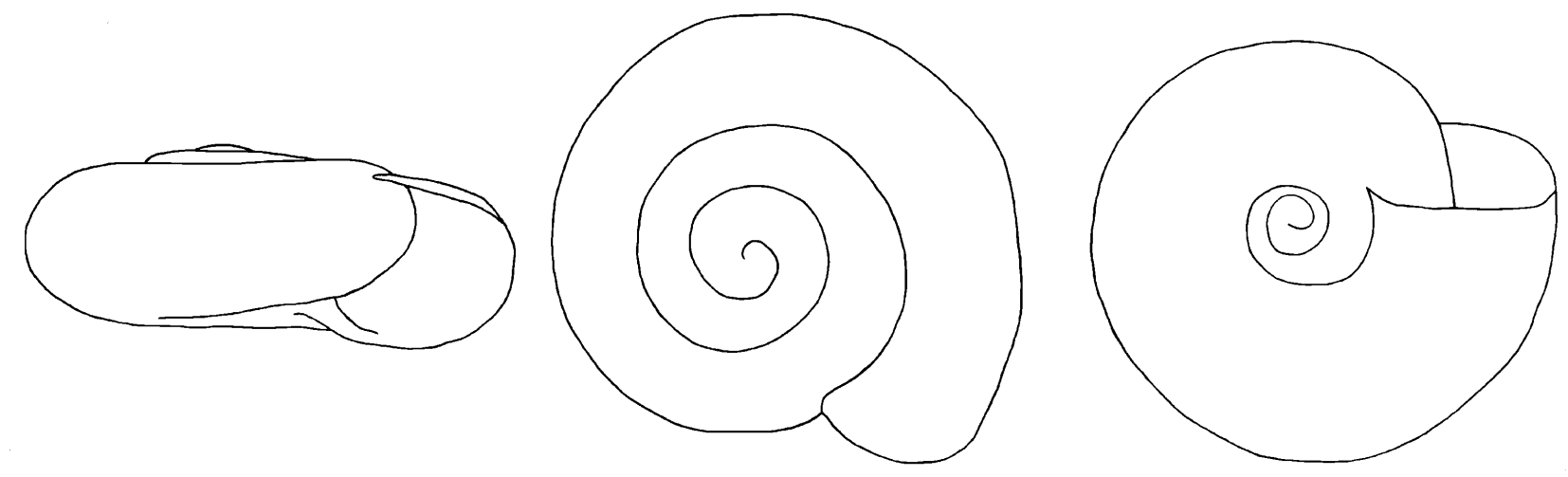

Fig. 4. Lucilla singleyana from Starobeshevo, shell width $2 \mathrm{~mm}$. Drawing by I. A. Balashov. 


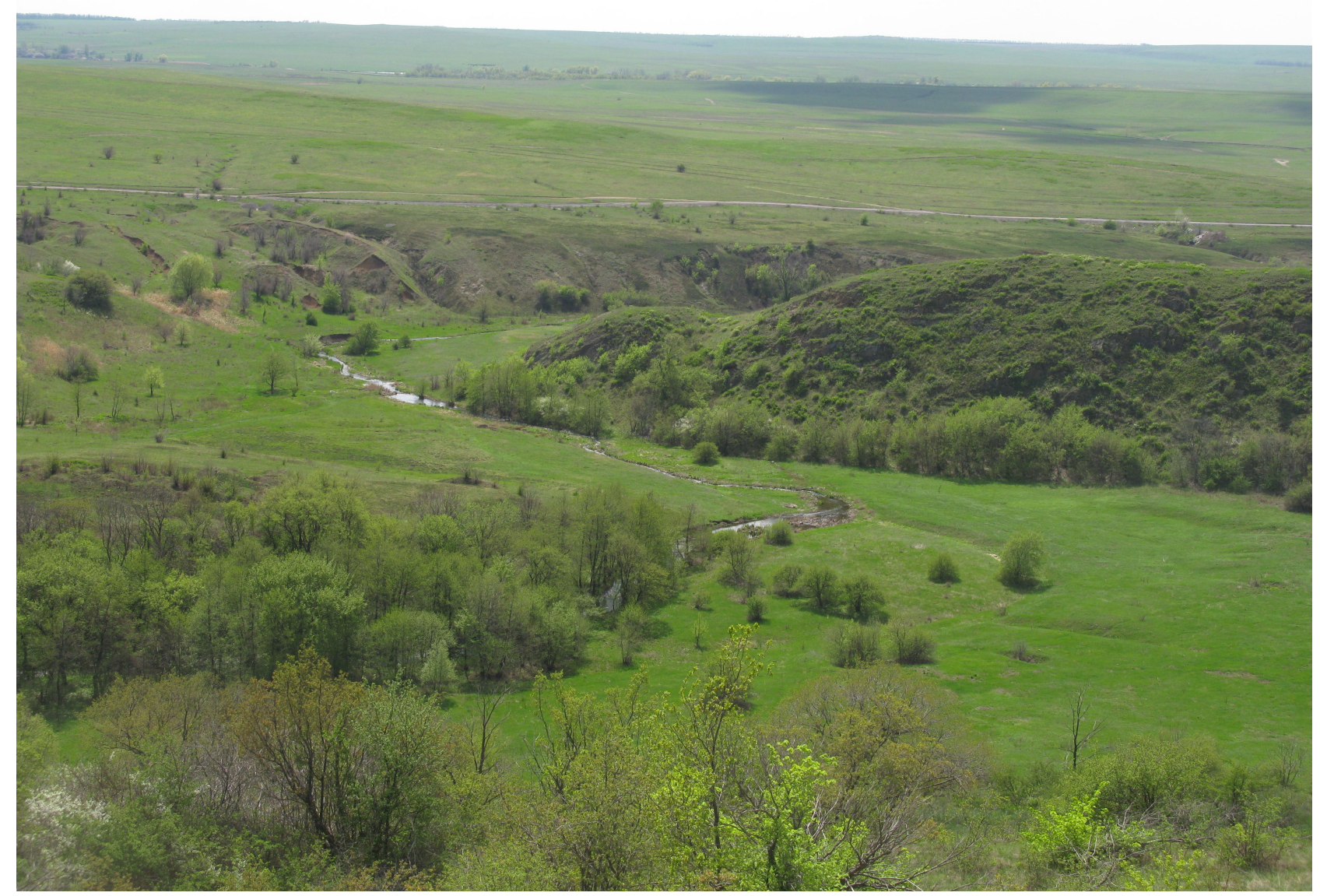

Fig. 5. The valley of Nagolna River near Nagolno-Tarasivka (locality No. 9). Photo by I. A. Balashov.

scarpathian region (BAIDASHNIKOV 1985). We have compared these two shells from Transcarpathia with a shell from Donetsk Upland and it seems to be similar, latter shell is slightly larger. According to the revision of HoRSÁK et al. (2009), shells from the both locations belong exactly to $L$. singleyana and not to the second species of this genus, L. scintilla (Lowe, 1852). Moreover, a photo of shell from Khmelnitsky region (Western Ukraine) identified as L. singleyana is shown in catalogue of SysOEV \& SCHILEYKO (2009), but it seems not to be Lucilla (BALASHOv \& GURAL-SVERLOVA 2012).

In Mariupol City (locality No. 7), Pupilla triplicata (Studer, 1820), V. pellucida, H. albescens, S. oblonga and Oxychilus sp. were found. In the latter case only empty shells were collected, and therefore a precise identification is not possible. Among the species known from Ukraine, these shells may belong to Oxychilus translucidus (Mortillet, 1854), O. draparnaudi (Beck, 1837) or O. diaphanellus (Krynicki, 1836). None of these species have been reported in southeastern Ukraine yet.

Also in this location (No. 7) a single shell of Pupilla sp. were found (Fig. 3F). According to its comparatevely large width, $1.7 \mathrm{~mm}$, normally it should be determined as $P u$ pilla muscorum (Linnaeus, 1758). All shells of P. triplicata in the same site were of $1.5 \mathrm{~mm}$ width. However, in spite of the fact that P. muscorum is widespread in Holarctic and lives mainly in dry open habitats, it was not revealed in the southeastern Ukraine, where such habitats predominate (BALASHov \& GuRAL-Sverlova 2012). Moreover, the shape of this shell is quite untypical for Ukrainian populations of this species, though similar shape was reported for P. muscorum (SCHiLeyкo 1984). Perhaps this shell is a specimen of $P$. triplicata which has some abnormalities in development (genetic or as a result of parasite activity).

An extensive material was collected in the Provalskyi Step branch of Lugansk Nature Reserve (locality No. 8). At these steppe sites $V$. costata, V. pulchella, C. lubricella, P. triplicata, T. cylindrica, C. tridens, V. pellucida and C. vindobonensis were found. In the forest belt of the black locust and common maple, $C$. vindobonensis, V. costata, C. lubricella, V. pellucida and Truncatellina sp. were found. In the litter of maple-ash forest on the river bank, Vertigo pusilla Müller, 1774, C. lubrica, Aegopinella minor (Stabile, 1864) and Euconulus fulvus (Müller, 1774) were found. The most unusual material was collected on the bottom of ravine along a stream in the litter of maple-ash forest. Species V. costata, Truncatellina costulata (Nilsson, 1823), Vertigo pygmaea (Draparnaud, 1801), P. pygmaeum, E. fulvus, Z. nitidus, P. hammonis, F. fruticum and $S$. oblonga were found there. The finding of T. costulata is of a special interest. In Ukraine this species occurs mainly on the Podolian Upland, forest-steppe zone of Middle Dnieper Area (Central Ukraine) and in the Crimean Mountains. Outside these territories in Ukraine, only few locations of $T$. costulata are known in good preserved forests of Eastern Ukraine (Balashov et al. 2009, GuRAL-SverLOVA et al. 2012). It is notable that those specimens were collected here on the ravine bottom along the stream. In 
Central Ukraine this species lives mainly in the relatively dry and elevated forests, but not in wet ravines (BALASHOV \& BAIDASHNIKOV 2010, 2012). Probably in the region with drier climate the most favorable humidity for this species could be found in another habitat. The occurrence of V. pygmaea in this habitat is also unusual. This is xerophile species that usually lives in dry open habitats and only sometimes in dry forests. There are four shells of $V$. pygmaea and 16 shells of $T$. costulata, all shells of first species and most of second are fresh with dried snail bodies, so it is probably that these snails were collected live and it is very unlikely that shells were accidentally transferred to the bottom of ravine.

A rich material was also collected in the upper valley of Nagolna River and along its two right tributaries in Nagolnyj Krjazh small nature reserve (so called "zakaznik") that was created in 2012 (locality No. 9; Fig. 5). In riparian oak-poplar forests species $C$. lubrica, $C$. nitens, $V$. costata, V. pusilla, Discus ruderatus (Férussac, 1821), P. pygmaeum, E. fulvus, Z. nitidus, A. minor, P. hammonis, $V$. pellucida, D. subagreste, P. rubiginosa and E. strigella were found. Most of these species are quite rare in southeastern Ukraine. In steppe areas, mostly in steep rocky slopes with outcrops, C. lubricella, Vallonia excentrica Sterki, 1893, V. costata, V. pulchella, P. triplicata, V. pygmaea, V. antivertigo (Draparnaud, 1801), T. cylindrica, C. tridens, $V$. pellucida, E. strigella and S. oblonga were found. In flat steppe areas without outcrops and visible microrelief, mainly $C$. tridens was seen, sometimes together with $V$. pulchella and C. lubricella. Partly this is maybe due to the natural favorability of such slopes with outcrops. However, it seems to be significant that the majority of the flat steppes near Nagolno-Tarasivka are overgrazed and, at least several times a year, intentional man-made grassland fires take place there. At the same time, steep slopes with outcrops are not suitable for grazing and grassland fires usually do not raise high on the rocky steppe slopes, and thanks to microrelief and outcrops there are lots of unburned places (as seen in the direct field observations).

It is unusual that $V$. antivertigo, which lives only in wet habitats, was only found among the rocks and stones on the dry steppe slope above Nagolna River near NagolnoTarasivka, and was not found on its banks.

Coloration variability in D. subagreste from the meadow and forest on the bank of Nagolna River (Fig. 5) is rather notable. According to literature (WIKTOR 2000, GuRAL-Sverlova et al. 2009), the coloration of this species is dark creamy, pale coffee or sometimes white, usually with a net of dark spots covered the whole slug's body (but sometimes it is poorly seen or almost absent), and a single appreciable dark spot (usually looking as a crescent) is always (!) present around the pneumostome. The same coloration was observed in all specimens of $D$. subagreste previously collected in the territory of Ukraine, including other specimens from Lugansk region (GURAL-SvERLOVA et al. 2009) and also above-mentioned slugs from Tokmak vicinities (locality No. 2). Two of the five specimens collected along the Nagolna River also have the same coloration (Fig. 6). However, another three specimens have no dark net and no dark spot around the pneumostome
(Fig. 7). No transitional forms were found. Only the head in light colored slugs is darker than the main coloration, which is also characteristic for the specimens with usual coloration. The structure of reproductive system in slugs with different coloration has no differences. All five slugs collected along the Nagolna River have sacciform penis divided by constriction into two sections with one long penial gland and dark spot at its base (differently pronounced and shaped), additional muscle is attached to the rear of penis, and stimulator is large, flat and fan-shaped. Consequently, described coloration differences are most likely examples of previously not-known intraspecific variability of $D$. subagreste.

\section{References}

BAIDASHNIKOV A. A., 1985: Terrestrial molluscs of Transcarpathian region and their distribution in main landscapes and phytocenoses. - Proceedings of the Zoological Institute of USSR Academy of Sciences, 135: 44-66. (in Russian)

Balashov I. A. \& Baidashnikov A. A., 2010: Terrestrial molluscs (Gastropoda) of the forest-steppe in the Dnieper Area and their confinement to different phytocenoses. - Vestnik Zoologii, 44(4): 309-316. (in Russian)

Balashov I. A. \& Baidashnikov A. A., 2012: Terrestrial molluscs (Gastropoda) of Vinnytsia region and their confinement to different phytocenoses. - Vestnik Zoologii, 46(1): 19-28. (in Russian)

Balashov I. A., Biatov A. P. \& Vasyliuk A. V., 2009: Species composition and confinement to different phytocenoses of terrestrial molluscs (Gastropoda, Pulmonata) in the "Homilshanski Lisy" National Nature Park (Ukraine, Kharkiv region). - Vestnik Zoologii, 43(4): 355-360. (in Russian)

BALASHOV I. \& GURAL-SvERLOVA N., 2012: An annotated checklist of the terrestrial molluscs of Ukraine. - Journal of Conchology, 41(1): 91-109.

Gural-Sverlova N. V., 2010: Review of terrestrial molluscs from the genus Helicopsis (Hygromiidae) of Donetsk upland and adjoining territories with description of new species. - Ruthenica, 20 (1): 13-26. (in Russian)

Gural-Sverlova N. V., 2012: Preliminary results of anatomical study of molluscs of the genus Helicopsis (Hygromiidae) of Crimea and Black Sea Lowland. - Ruthenica, 22(1): 15-34. (in Russian)

Gural-Sverlova N. V., Balashov I. A. \& Gural R. I., 2009: Recent distribution of terrestrial molluscs from family Agriolimacidae in Ukraine. - Ruthenica, 19(2): 53-61. (in Russian)

Gural-Sverlova N. V., Martynov V. V. \& Martynov A. V., 2012: Terrestrial molluscs (Gastropoda, Pulmonata) of Donetsk upland and adjoining territories. - Vestnik Zoologii, 46(4): 319-326. (in Russian)

HorsÁK M., ŠTEFFEK J., Č́EJKA T., LožEK V. \& JuŘIČKovÁ L., 2009: Occurrence of Lucilla scintilla (R.T. Lowe, 1852) and Lucilla singleyana (Pilsbry, 1890) in the Czech and Slovak Republics - with remarks how to distinguish these two non-native minute snails. - Malacologica Bohemoslovaca, 8: 24-27.

Khlus L. N. \& TKachuK A. D., 2012: Conchological characteristics of Helix lucorum L. colony from Odessa. - Naukovi zapysky Ternopil's'kogo nacional'nogo universytetu imeni Volodymyra Gnatjuka. Serija: Biologija, 51(2), special issue "Mollusks: Results, Problems and Perspectives of the Investigations": 290-294. (in Russian)

LeONov S. V., 2006: The first record of the Helix lucorum var. martensii Boettger, 1883 (Gastropoda; Pulmonata) in Kerch peninsula. - Vestnik zoologii, 40(1): 76. (in Russian)

Parnikoza I. \& VAsiluk A., 2011: Ukrainian steppes: current 
state and perspectives for protection. - Annales Universitatis Mariae Curie-Skłodowska. Sectio C, 66(1): 23-37.

Schileyko A. A., 1978: Terrestrial molluscs of the superfamily Helicoidea [Fauna SSSR. Mollusca, Vol. 3, No. 6]. - Leningrad, Nauka, 384 pp. (in Russian)

Schileyko A. A., 1984: Terrestrial mollusks of the suborder Pupillina of the USSR fauna (Gastropoda, Pulmonata, Geophila) [Fauna SSSR. Mollusca, Vol. 3, No. 3]. - Leningrad, Nauka, 399 pp. (in Russian)

STANKOWSKI S., 2011: Extreme, continuous variation in an island snail: local diversification and association of shell form with the current environment. - Biological Journal of the Linnean
Society, 104: 756-769.

Stoyko T. G. \& Bulavkina O. V., 2010: Guide for terrestrial molluscs of the forest-steppe zone of the right-bank Volga area. - Moscow, KMK, 96 pp. (in Russian)

Sysoev A. \& Schileyko A., 2009: Land snails and slugs of Russia and adjacent countries [Pensoft Series Faunistica 87]. - SofiaMoscow, Pensoft Publishers, 455 pp.

Welter-Schultes F. W., 2012: European non-marine molluscs, a guide for species identification. - Planet Poster Editions, Göttingen, $757 \mathrm{pp}$.

WikTor A., 2000: Agriolimacidae (Gastropoda: Pulmonata) - a systematic monograph. - Annales Zoologici, 49(4): 347-590.

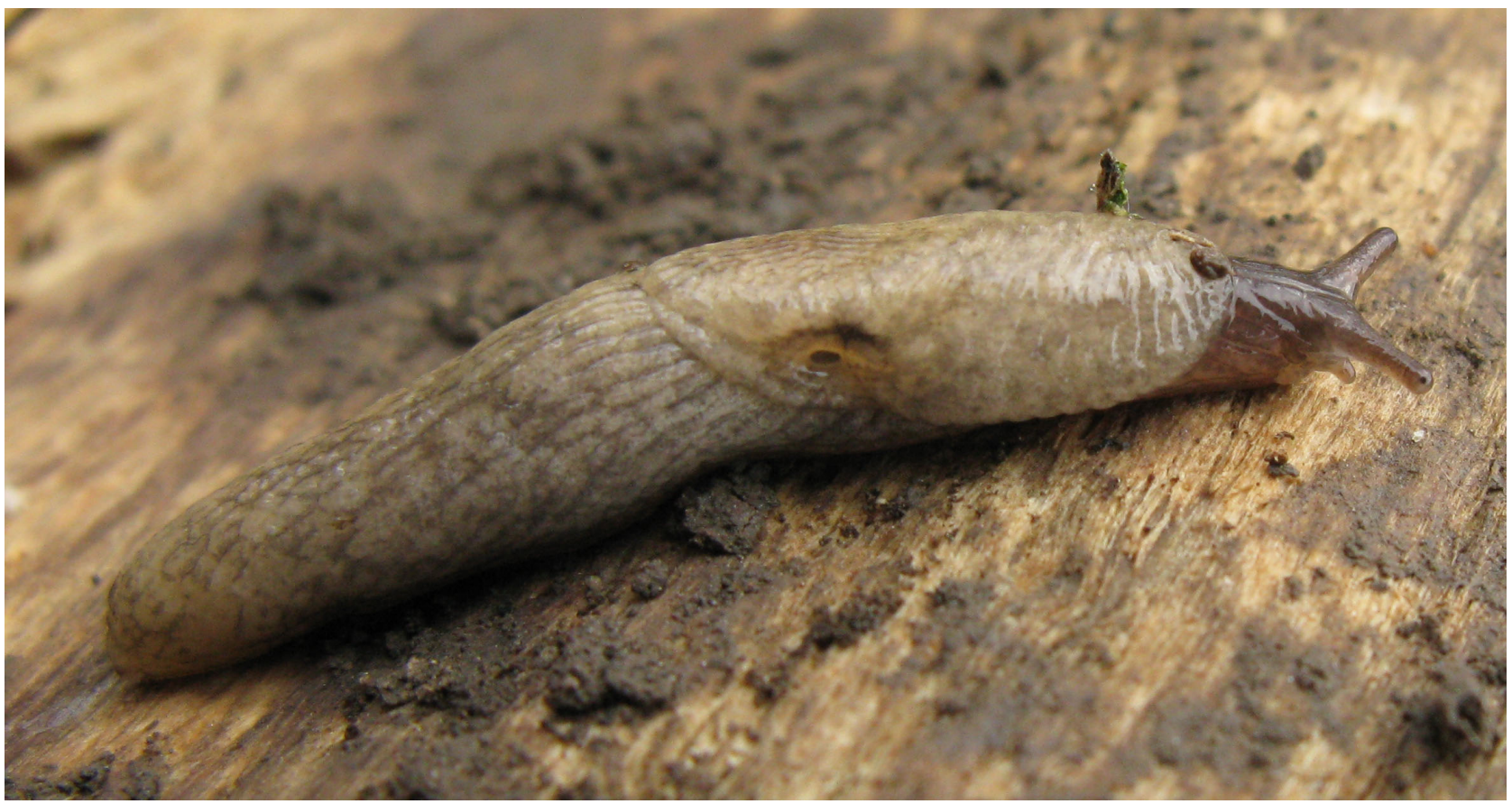

Fig. 6. Deroceras subagreste from the valley of Nagolna River, specimen with usual coloration. Photo by I. A. Balashov.

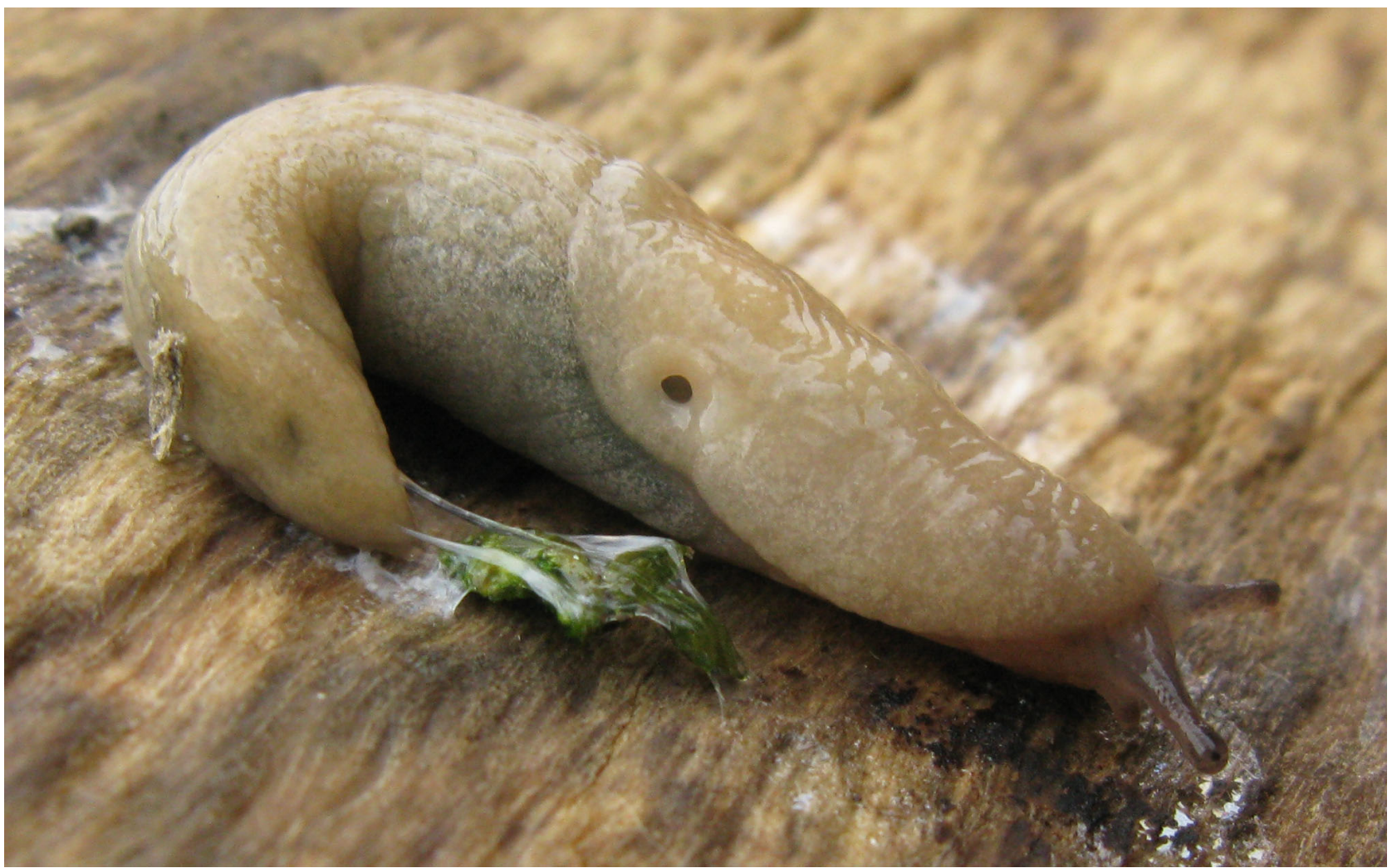

Fig. 7. Deroceras subagreste from the valley of Nagolna River, specimen with pale coloration. Photo by I. A. Balashov. 